\title{
PENINGKATAN KEMAMPUAN KOMUNIKASI MATEMATIS SISWA SMP MELALUI PEMBELAJARAN PENEMUAN TERBIMBING
}

\author{
Riska Novia Sari, \\ Dosen Tetap Prodi Pendidikan Matematika Universitas Riau Kepulauan
}

\begin{abstract}
ABSTRAK
Penelitian ini bertujuan mengkaji masalah peningkatan kemampuan komunikasi matematis siswa sebelum dan sesudah belajar melalui pembelajaran penemuan terbimbing dan konvensional. Penelitian ini merupakan penelitian quasi experiment dengan desain kelompok kontrol non ekivalen. Populasi penelitian adalah siswa kelas IX SMPN 3 Lembang. Sampel terdiri dari kelas IX $_{\mathrm{A}}$ sebagai kelompok kontrol dan kelas $\mathrm{IX}_{\mathrm{B}}$ sebagai kelompok eksperimen. Instrumen yang digunakan terdiri dari instrumen tes dan lembar observasi. Data dianalisis menggunakan uji Mann-Whitney. Hasil penelitian menunjukkan bahwa: peningkatan kemampuan komunikasi matematis siswa yang belajar melalui pembelajaran terbimbing lebih baik dari pada siswa yang belajar melalui pembelajaran konvensional.
\end{abstract}

Kata Kunci: pembelajaran penemuan terbimbing, kemampuan komunikasi matematis

\begin{abstract}
The aim of this study was to investigate problem about enhancing of mathematical communication ability of student before and after using guided discovery learning. This study used quacy experiment research which combined nonequivalent control group design. The target population in this study was the ninth grade of Junior High School (SMPN) 3 Lembang which included $X I_{A}$ class as experimental group and $X I_{B}$ class as control group. The data were collected with an aid of several instruments i.e. test and observation sheet. The data was analyzed using the Mann-Whitney test. Findings of this study showed that enhancing of student's mathematical communication who get guided discovery learning is better than student who get conventional learning.
\end{abstract}

Keywords: guided discovery learning, mathematical communication ability, 


\section{Pendahuluan}

Salah satu upaya meningkatkan kualitas pendidikan, yaitu meningkatkan kualitas pembelajaran matematika di sekolah. Hal ini karena matematika sebagai ilmu, memiliki struktur dan keterkaitan yang kuat dan jelas antar konsepnya sehingga memungkinkan siswa terampil berpikir rasional. National Council of Teachers of Mathematics (NCTM, 2000) merumuskan tujuan pembelajaran matematika diantaranya yaitu: (1) belajar untuk berkomunikasi; (2) belajar untuk bernalar. Berdasarkan tujuan tersebut, tercermin bahwa kemampuan komunikasi merupakan aspek penting dalam pembelajaran matematika.

Baroody menyatakan dua alasan pentingnya kemampuan komunikasi dalam pembelajaran matematika yaitu: (1) matematika sebagai bahasa, artinya matematika sebagai alat untuk mengkomunikasikan berbagai ide dengan jelas, tepat dan cermat, bukan hanya sebagai alat bantu berpikir, menemukan pola, atau menyelesaikan masalah; (2) matematika sebagai aktivitas sosial, yaitu matematika sebagaimana halnya interaksi antar siswa, komunikasi guru dan siswa merupakan bagian penting untuk memelihara dan mengembangkan potensi matematika siswa (Hutapea, 2012). Namun kenyataan yang terjadi di lapangan masih jauh dari yang diharapkan. Hasil studi pendahuluan yang dilakukan oleh Scristia (2014) terhadap 13 orang siswa MTsN Kosamalang Bandung terkait dengan materi bangun ruang sisi lengkung, soal yang diberikan meminta siswa untuk melukiskan ide-ide matematika ke dalam bentuk gambar.

Upaya untuk meningkatkan kemampuan matematis yaitu dengan merancang suatu pendekatan pembelajaran yang lebih banyak melibatkan interaksi siswa secara aktif dan penemuan dalam proses pembelajaran sehingga dapat menggali potensi dan meningkatkan kemampuan yang dimilikinya. Hal ini dipertegas oleh pendapat Henningsen \& Stein (1997) bahwa tanpa terlibat secara aktif selama pembelajaran di kelas, siswa tidak dapat mengembangkan kapasitas berpikir, bernalar, dan memecahkan masalah matematis secara tepat dan kuat. Salah satu model pembelajaran yang diharapkan dapat memfasilitasi siswa dalam meningkatkan kemampuan komunikasi matematis yaitu pembelajaran penemuan terbimbing.

Dalam pembelajaran penemuan terbimbing guru menyediakan masalah dan mendorong siswa untuk menyelesaikan masalah tersebut secara berkelompok. Guru bertindak sebagai penunjuk jalan, membantu siswa agar mempergunakan konsep, ide-ide dan keterampilan yang telah dipelajari sebelumnya untuk memperoleh pengetahuan yang baru. Bimbingan ini merupakan pengarahan yang dapat berbentuk pertanyaan-pertanyaan baik secara lisan ataupun tulisan yang dituangkan dalam LKS. Pengajuan pertanyaan yang tepat oleh guru akan 
merangsang kreativitas dan siswa menemukan pengetahuan yang baru. Pengetahuan yang baru akan melekat lebih lama jika siswa dilibatkan secara langsung dalam proses pemahaman dan mengonstruksi konsep atau prinsip pengetahuan tersebut.

Siswa diharapkan dapat mencari dan menemukan sendiri jawaban dari suatu masalah yang dipertanyakan dengan cara melakukan pengamatan, mengumpulkan data, menganalisis dan menarik kesimpulan. Dengan demikian model pembelajaran penemuan terbimbing diharapkan dapat meningkatkan kemampuan komunikasi matematis siswa.

Pembelajaran penemuan terbimbing berorientasi pada student centered (Rooney, 2009). Tahapan pembelajaran penemuan terbimbing yang akan dilakukan dalam penelitian ini dimodifikasi dari tahapan pembelajaran penemuan terbimbing menurut Markaban (2006) yaitu: (1) apersepsi, (2) pengajuan masalah, (3) mengajukan konjektur, (4) mengumpulkan data, (5) menguji konjektur, dan (6) merumuskan kesimpulan.

Penelitian ini bertujuan untuk mengkaji peningkatan kemampuan komunikasi matematis antara siswa yang belajar melalui pembelajaran penemuan terbimbing dan siswa yang belajar melalui pembelajaran konvensional.

\section{Metode Penelitian}

Jenis penelitian yang digunakan yaitu penelitian kuasi eksperimen dengan desain penelitian Non-equivalent Control Group Design.

Populasi dalam penelitian ini adalah semua siswa kelas IX pada salah satu SMPN di Kabupaten Bandung Barat semester ganjil Tahun Ajaran 2014/2015. kelas IX A sebagai kelompok kontrol dan kelas IX B $_{\mathrm{B}}$ sebagai kelompok eksperimen. Variabel dalam penelitian ini ada dua yaitu variabel bebas dan terikat. Variabel bebas disini yaitu model pembelajaran. Sedangkan variabel terikatnya yaitu kemampuan komunikasi matematis siswa.

Instrumen yang digunakan dalam penelitian ini adalah tes kemampuan komunikasi matematis yang terdiri dari 3 soal dalam bentuk uraian. Analisis data hasil ujicoba menggunakan Teori Respon Butir/Model Rasch (atau Item Response Theory, IRT). Analisis data dengan Model Rasch dilakukan dengan bantuan software Winstep 3.73. teknik analisis data yang diperoleh dari hasil pretes dan postes kemampuan komunikasi matematis diolah dengan bantuan Microsoft Excell 2010 dan software SPSS 16 for Windows.

\section{Hasil dan Pembahasan}

\section{Hasil}


Berikut ini deskripsi data pretes, postes, dan N-gain kemampuan komunikasi pada kelompok eksperimen dan kelompok kontrol terdistribusi pada Tabel 1 dan 2 berikut.

Tabel 1. Nilai Kelompok Eksperimen

\begin{tabular}{|l|c|c|c|c|}
\hline \multicolumn{1}{|c|}{ Nilai } & $\overline{\boldsymbol{x}}$ & $\mathrm{Sd}$ & $X_{\max }$ & $X_{\min }$ \\
\hline Pretes & 7,56 & 2,35 & 12 & 4 \\
\hline Postes & 16,02 & 4,27 & 27 & 9 \\
\hline N-Gain & 0,42 & 0,18 & 0,95 & 0,17 \\
\hline
\end{tabular}

Tabel 2. Nilai Kelompok Kontrol

\begin{tabular}{|l|c|c|c|c|}
\hline \multicolumn{1}{|c|}{ Nilai } & $\overline{\boldsymbol{x}}$ & $\mathrm{Sd}$ & $X_{\max }$ & $X_{\min }$ \\
\hline Pretes & 8,40 & 3,52 & 22 & 5 \\
\hline Postes & 14,14 & 5,19 & 27 & 8 \\
\hline N-Gain & 0,32 & 0,21 & 0,88 & 0,09 \\
\hline
\end{tabular}

Berdasarkan Tabel 1 dan 2 dapat terlihat bahwa rataan skor pretes kemampuan komunikasi tidak jauh berbeda sebelum belajar melalui pembelajaran penemuan terbimbing dan pembelajaran konvensional. Begitu juga dengan standar deviasi skor pretes kedua kelompok juga tidak menunjukkan perbedaan yang cukup besar artinya penyebaran data pada kedua kelompok relatif sama. Dari data terlihat bahwa terjadi peningkatan skor kemampuan komunikasi matematis siswa setelah pembelajaran dilaksanakan. Selanjutnya untuk perbandingan rataan $\mathrm{N}$-gain kemampuan komunikasi matematis dapat dilihat pada Gambar 1 berikut.

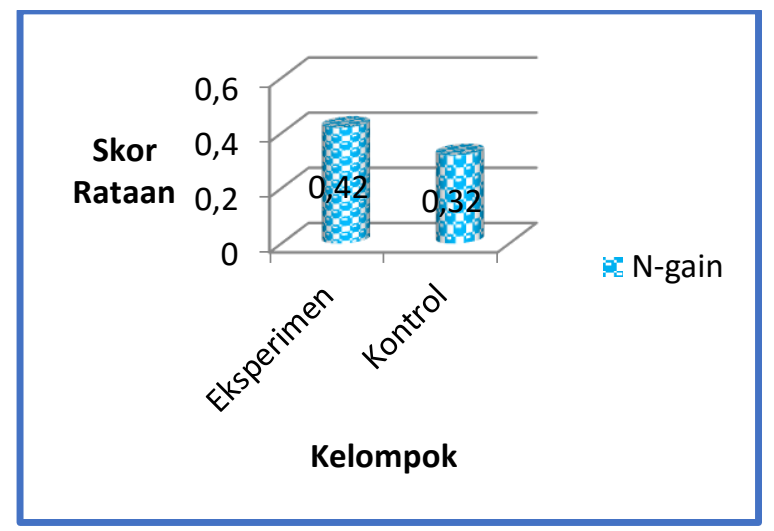

Gambar 1. Perbandingan Rataan N-gain 
Berdasarkan Gambar 1 rataan N-gain kelompok eksperimen dan kelompok kontrol berada pada klasifikasi sedang. Rataan $\mathrm{N}$-gain kelompok eksperimen lebih tinggi 0,1 dari rataan N-gain kelompok kontrol.

Uji normalitas kedua kelompok untuk kemampuan komunikasi matematis menunjukkan bahwa skor pretes kedua kelompok berdistribusi normal. Dilanjutkan dengan uji homogenitas diperoleh nilai sig. untuk kedua kelompok lebih besar dari 0,05 yaitu 0,379, sehingga $\mathrm{H}_{\mathrm{o}}$ diterima. Artinya, varians populasi data pretes kemampuan komunikasi matematis siswa kelompok eksperimen dan kelompok kontrol homogen, maka dilanjutkan dengan uji t. Dengan uji t diperoleh nilai Sig. (2-tailed $)=0,213>0,05$. Kesimpulannya $\mathrm{H}_{0}$ diterima, yaitu tidak terdapat perbedaan yang signifikan antara data pretes kemampuan komunikasi matematis siswa kelompok eksperimen dan kontrol.

Untuk mengetahui peningkatan kemampuan komunikasi matematis antara siswa yang belajar melalui pembelajaran penemuan terbimbing dengan siswa yang belajar melalui pembelajaran konvensional, maka dilakukan analisis terhadap kelompok $\mathrm{N}$-gain antara siswa yang memperoleh kedua pembelajaran tersebut.

Pertama dilakukan uji normalitas, diperoleh bahwa data $\mathrm{N}$-gain kemampuan komunikasi matematis pada salah satu kelompok berdistribusi tidak normal, sehingga untuk menentukan uji perbedaan rataan dilakukan dengan uji non parametrik. Diperoleh nilai sig. (1tailed) kemampuan komunikasi 0,0005 $<\propto$, ini menyatakan $\mathrm{H}_{0}$ ditolak. Dengan demikian dapat disimpulkan bahwa peningkatan kemampuan komunikasi matematis siswa yang belajar melalui pembelajaran penemuan terbimbing secara signifikan lebih baik dibandingkan dengan siswa yang belajar secara konvensional.

Selanjutnya lembar observasi siswa dan guru yang digunakan untuk mengetahui aktivitas guru dan siswa selama pembelajaran penemuan terbimbing. Observasi dilakukan enam kali pertemuan selama proses pembelajaran oleh seorang observer. Hasil penilaian yang dilakukan pada setiap aspek kegiatan guru dan siswa dinyatakan dalam kategori penilaian, yaitu sangat baik diberi skor 5, baik diberi skor 4, cukup diberi skor 3, kurang diberi skor 2 dan kategori sangat kurang diberi skor 1. Berikut tabel keterlaksanaan aktivitas guru dan siswa,

Tabel 3. Aktivitas Guru

\begin{tabular}{|c|c|c|}
\hline Pertemuan ke- & Persentase & Kategori \\
\hline 1 & 58,6 & Cukup \\
\hline 2 & 67,2 & Cukup \\
\hline 3 & 74,3 & Baik \\
\hline
\end{tabular}




\begin{tabular}{|c|c|c|}
\hline 4 & 80,0 & Baik \\
\hline 5 & 82,9 & Baik \\
\hline 6 & 82,9 & Baik \\
\hline $\begin{array}{c}\text { Rata-rata } \\
\text { Keterlaksanaan }\end{array}$ & $\mathbf{7 4 , 3 1}$ & Baik \\
\hline
\end{tabular}

Tabel 3 memperlihatkan gambaran secara keseluruhan aktivitas guru yang dalam hal ini adalah peneliti sendiri yang menerapkannya hampir berjalan dengan baik. Hal ini ditandai dengan rata-rata persentase keterlaksanaan aktivitas guru mencapai $74,31 \%$, yaitu termasuk kategori baik. Pada pertemuan pertama dan kedua persentase keterlaksanaan aktivitas guru berada pada kategori cukup, sedangkan pada pertemuan berikutnya meningkat menjadi kategori baik.

Tabel 4. Aktivitas Siswa

\begin{tabular}{|c|c|c|}
\hline Pertemuan ke- & Persentase & Kategori \\
\hline 1 & 38,6 & Kurang \\
\hline 2 & 47,1 & Kurang \\
\hline 3 & 57,1 & Cukup \\
\hline 4 & 68,6 & Cukup \\
\hline 5 & 71,4 & Cukup \\
\hline 6 & 74,3 & Baik \\
\hline $\begin{array}{c}\text { Rata-rata } \\
\text { Keterlaksanaan }\end{array}$ & $\mathbf{5 9 , 5 1}$ & Cukup \\
\hline
\end{tabular}

Berdasarkan Tabel 4 terlihat aktivitas siswa pada pembelajaran penemuan terbimbing di setiap pertemuan mengalami peningkatan, dengan rataan keseluruhan aktivitas siswa yaitu 59,5\%, yaitu termasuk katageri cukup.. Pada pertemuan pertama dan kedua persentase keterlaksanaan aktivitas siswa berada pada kategori sedang, kemudian pada pertemuan ketiga sampai pertemuan kelima meningkat menjadi kategori cukup dan pertemuan keenam meningkat menjadi kategori baik.

\section{Pembahasan}

Pembelajaran penemuan terbimbing menunjukkan peran yang berarti dalam meningkatkan kemampuan komunikasi matematis siswa. Melalui pembelajaran penemuan 
terbimbing ini siswa diberikan kesempatan untuk menemukan jawaban permasalahan yang diberikan oleh guru dalam LKS melalui diskusi kelompok. Aktivitas diskusi kelompok difasilitasi pada tahapan pembelajaran penemuan terbimbing yaitu pada tahap mengajukan konjektur, mengumpulkan data dan menguji konjektur. Gambar berikut memperlihatkan aktivitas siswa berdiskusi dengan teman sekelompoknya.

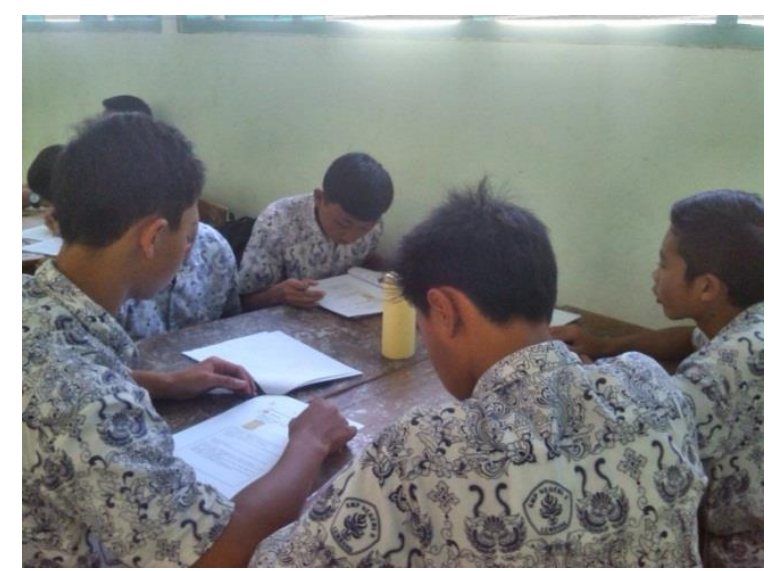

Gambar 2

Aktivitas Siswa Berdiskusi dengan Teman Kelompoknya

Berdasarkan Gambar 2 terlihat siswa memahami LKS yang diberikan oleh guru untuk kemudian didiskusikan dalam kelompok. Pada tahapan tersebut siswa diharapkan dapat menyusun konjektur untuk menduga dan menemukan jawaban dari permasalahan yang diajukan guru, kemudian siswa mengumpulkan data-data untuk menguji konjektur tersebut, kemudian siswa melakukan analisis dan pada akhirnya siswa mampu menyimpulkan temuantemuan mereka. Pembelajaran penemuan terbimbing dengan berkelompok diharapkan dapat meningkatkan kemampuan komunikasi siswa. Hal ini didukung oleh pendapat Brenner (1998) bahwa kelompok-kelompok kecil dalam pembelajaran maka akan meningkatkan kemampuan komunikasi siswa, karena intensitas siswa dalam mengemukakan pendapatnya semakin tinggi. Turmudi (2009) juga menyatakan bahwa proses komunikasi matematika dapat difasilitasi dengan adanya kerja kelompok, baik komunikasi matematika tertulis maupun komunikasi lisan.

Penemuan di lapangan terkait dengan jawaban tes kemampuan komunikasi siswa yang belajar melalui pembelajaran penemuan terbimbing jika dibandingkan dengan siswa yang belajar melalui pembelajaran konvensional lebih rinci dapat dilihat dari soal kemampuan komunikasi dengan menyatakan suatu situasi atau masalah matematik atau kehidupan sehari- 
hari ke dalam bentuk gambar, diagram, bahasa atau symbol matematika; atau model matematika.

Tiga buah kerucut masing-masing berjari-jari $r_{1}, r_{2}$, dan $r_{3}$ dimana jari-jari kerucut pertama dua kali jari-jari kerucut kedua, dan jari-jari kerucut kedua satu per tiga jari-jari kerucut ketiga. Diketahui jari-jari kerucut ketiga yaitu $6 \mathrm{~cm}$. Tinggi kerucut pertama dua kali tinggi kerucut kedua dan tinggi kerucut ketiga sama dengan tinggi kerucut kedua yaitu $5 \mathrm{~cm}$.

a. Ilustrasikan permasalahan di atas dalam bentuk gambar!

b. Tentukanlah perbandingan volume ketiga kerucut tersebut!

Berikut jawaban siswa kelompok eksperimen dan kelompok kontrol dalam menjawab soal di atas.

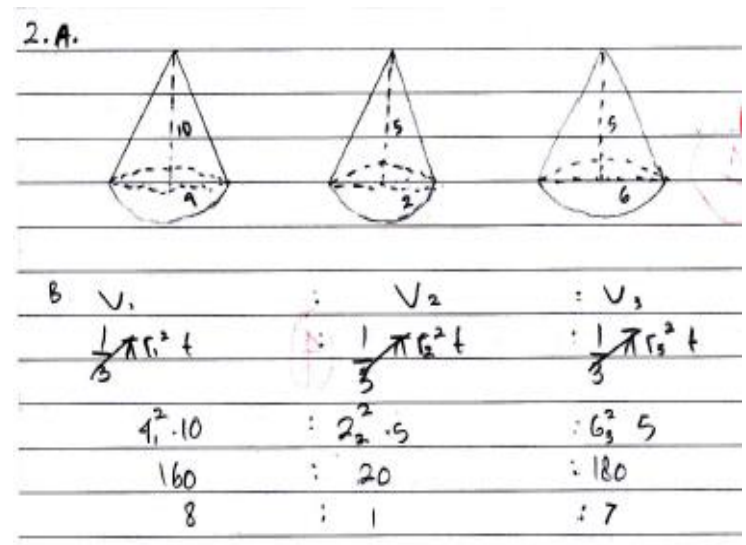

Gambar 3

Jawaban Salah Seorang Siswa Kelompok Kontrol

Berdasarkan Gambar 3 di atas terlihat bahwa, siswa kelompok kontrol masih lemah dalam menyatakan suatu situasi matematika ke dalam bentuk gambar, dimana ukuran jari-jari dan tinggi kerucut berbeda tetapi siswa menggambar ketiga kerucut tersebut sama. Beberapa siswa diantaranya mencoba menggambarkan, namun jawaban mereka tidak sesuai. Temuan ini didasarkan pada skor postes kemampuan siswa kelas kontrol yang dapat dilihat pada lampiran D, terlihat bahwa untuk pertanyaan nomor 2a, tidak ada satupun siswa kelas kontrol yang dapat menyelesaikan dengan benar. Namun untuk pertanyaan nomor $2 b$, beberapa siswa dapat menyelesaikan dengan benar. Dapat disimpulkan bahwa siswa lebih mudah untuk melakukan perhitungan daripada menyatakan situasi ke dalam bentuk gambar. 


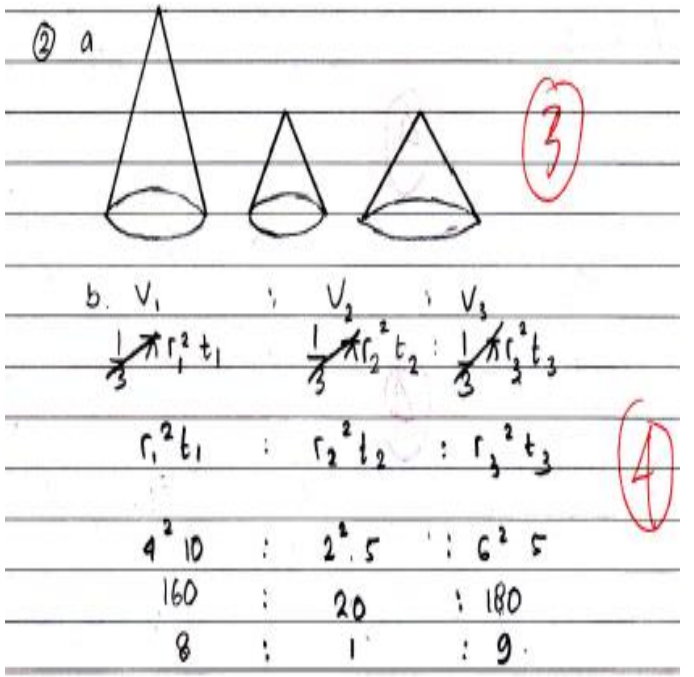

Gambar 4

Jawaban Salah Seorang Siswa Kelompok Eksperimen

Berbeda dengan siswa kelompok kontrol, berdasarkan Gambar 4 di atas terlihat jawaban siswa kelompok eksperimen sudah mendekati benar, walaupun jawaban siswa tersebut memiliki skor 3 dalam skala 0 sampai 4, tetapi kemampuan siswa menyatakan situasi kedalam bentuk gambar sudah terlihat.

Rendahnya kemampuan komunikasi matematis siswa pada kelompok konvensional disebabkan karena belum mampu menfasilitasi kemampuan siswa dalam mengkomunikasikan ide-ide matematisnya. Siswa hanya memperoleh informasi dari guru saja. Selain itu rangkaian aktivitas pada pembelajaran konvensional menyebabkan siswa hanya menghafal rumus dan langkah-langkah pengerjaan soal. Jika siswa diberikan permasalahan di luar konteks yang diajarkan, siswa merasa bingung karena tidak bisa mengaplikasikan pengetahuan mereka ke dalam konteks yang berbeda. Hal ini senada dengan hasil penelitian Erita (2009) bahwa guru cenderung mengajarkan siswa belajar dengan cara menghafal.

\section{Kesimpulan}

Berdasarkan hasil penelitian yang diperoleh setelah melakukan analisis dan pembahasan terhadap masalah yang telah dikemukakan dalam penelitian ini, dapat diambil kesimpulan bahwa peningkatan kemampuan komunikasi matematis siswa yang belajar melalui 
pembelajaran penemuan terbimbing lebih baik daripada siswa yang belajar melalui pembelajaran konvensional.

\section{Daftar Pustaka}

Hutapea, N. M. (2012). Peningkatan Kemampuan Penalaran, Komunikasi Matematis dan Kemandirian Belajar Siswa SMA Melalui Pembelajaran Generatif. (Disertasi), Sekolah Pascasarjana, Universitas Pendidikan Indonesia, Bandung.

Markaban. (2006). Model Pembelajaran Matematika dengan Pendekatan Penemuan Terbimbing. Depdiknas: Yogyakarta.

National Council of Teachers of Mathematics (NCTM). (2000). Principles and Standards of Mathematics Education. [Online]. Tersedia di: http://www.nctm.org. [24 Februari 2014].

Pape, S.J, et.al. (2003). "Developing Mathematical Thinking and Self-Regulated Learning: A Teaching Experimen in A Seventh-Grade Mathematics Classroom". Educational Studies in Mathematics. 53 ( 2), hlm. 179-202.

Robert Ronger. (1990). The 10 Habits of Highly Successful People: Powerful Strategies for Personal Triumphs. Malaysia: Wynwood Press.

Scristia. (2014). Meningkatkan Kemampuan Mathematical Visual Thinking dan Self-Efficacy Siswa SMP Melalui Metode Discovery Learning. (Tesis), Sekolah Pascasarjana, Universitas Pendidikan Indonesia, Bandung.

Shadiq, Fadjar. (2004). "Pemecahan Masalah, Penalaran dan Komunikasi". Makalah pada PPPG, Yogyakarta. 